\title{
Taming Volatile Capital Flows in Emerging Economies
}

\author{
Stephen Grenville ${ }^{1}$
}

Just about all economists agree that international trade in goods and services is beneficial and should be unrestricted. There is much less unanimity, however, on the benefits of international capital flows. The volatility and 'sudden stops' experienced over recent decades, especially in emerging economies, have provoked some rethinking. It is argued here that this re-think has much further to go before the analytical discussion fits the reality of capital-flow behaviour and policy comes to grips with the challenge of living with capricious capital flows. Flows to East Asian emerging economies illustrate the argument.

\section{Prologue}

The attitude to international capital flows has changed markedly since Bretton Woods established the framework and norms for international transactions after World War II. At the time of Bretton Woods (and for more than two decades afterwards) it was widely accepted that capital flows might be disruptive and should be treated differently from trade flows. Controls were not only acceptable, but were the norm.

With generalised floating of exchange rates in 1971, capital flows came to be seen as part of the equilibrating process, the more so because market-based outcomes had become the intellectual norm. The central policy message was that flows should be unimpeded by regulation or restrictions. Advocacy of unregulated capital flows reached its peak in 1997, with efforts to incorporate free capital flows into the IMF Articles, on a par with the commitment to free trade in goods and services (see IMF Independent Evaluation Office 2005). ${ }^{2}$

Now, a rethinking is under way, best illustrated by the IMF's shifting position. For decades a proselytiser for free capital flows, the active debate by the IMF staff over the past two years recognises the potential downside of excessive capital flows (Ostry et al. 2010; 2011). Even the more staid IMF Executive Board is prepared to countenance measures to manage flows (IMF 2012(a) and 2012(b)).

\footnotetext{
$1 \quad$ Lowy Institute, stephengrenville1@gmail.com

2 That said, even in this period there were voices disagreeing with these efforts — Bhagwati (1998), for example.
} 
Other international institutions are also exploring new ways of thinking about capital flows (at the Bank for International Settlements; see Borio and Disyatat 2011). These changes in mindset occur slowly, with some largely oblivious to the shift (see, for example, Yellen 2011).

\section{The analytical framework}

Neither the Mundell/Fleming framework (the workhorse of much policy thinking) nor the academically more-favoured intertemporal ${ }^{3}$ framework specifically addresses what is happening in financial markets. It is here, in sometime-aberrant market behaviour, that much of the volatile action and puzzles are to be found. It's often useful to think of these flows in the same way that financial markets view them, in terms of portfolio balance. Capital flows to where the (risk-adjusted) expected returns are highest.

This portfolio-based approach needs to be reconciled with the national accounts. Capital flows are, of course, identically equal to the savings/investment balance and also the current-account balance. ${ }^{4}$ Some general equilibrium process is needed to reconcile the different factors driving portfolio balance and the national accounting components. That said, capital flows have often been seen as the passive equilibrating mechanism which would, to a large extent, allow the national accounts components (consumption, savings and investment) to be the main determinants of the general equilibrium outcome. All that seemed to be required to make this work satisfactorily were well-functioning financial markets and capital flows which are unrestrained by regulation or controls. This was, indeed, the thrust of policy advice, particularly from the IMF. Where this narrative has departed from reality is that financial markets have not always been well-functioning.

\section{What are the characteristics of capital flows in practice?}

The flows are very volatile: The Mexican crisis (1994-5) and the Asian crisis (1997-8) demonstrated that capital flows were not a smooth equilibrium process with well-defined parameters, largely determined by interest differentials and stable exchange rate expectations. The inflows to emerging countries increased quite suddenly in the early 1990s. While not extraordinarily large in respect of the portfolios of investing countries, the inflows were huge relative to the

3 See Obstfeld and Rogoff (1994).

4 Including official flows such as foreign-exchange reserve holdings. 
financial sectors of the recipient countries, and large relative to their total GDP. A well-functioning market would have recognised that this magnitude of inflow could not be effectively absorbed without major disruption. These flows were not driven by well-founded judgements about market fundamentals, but were the lemming-like rushes of optimism followed by pessimism that characterise foreign capital flows to emerging countries. Higher interest rates were not effective in preventing the outflow, nor did large falls in exchange rates convince investors that future movements in the exchange rate would be reversionary appreciations. Balance-of-payments equilibrium was achieved not through changes in interest rates or exchange rates, but by painful falls in income large enough to produce substantial current-account surpluses, matching the capital outflows.

This is illustrated by the specific experience of Emerging Asia, shown below in Table $1 .{ }^{5}$ Note especially the volatility of the flows to the ASEAN-5 countries, where inflows exceeded 9 per cent of GDP in 1996, to be replaced by outflows almost as large a couple of years later. In 1996, Thailand, a relative neophyte as a capital importer, received inflow equal to 13 per cent of GDP. This capital departed over the next two years. Similar (although less extreme) variability was exhibited during the 2008 global financial crisis.

Table 1: Emerging Asia net private capital inflows, \% of GDP

\begin{tabular}{|c|c|c|c|c|c|c|c|c|c|}
\hline & 1995 & 1996 & 1997 & 1998 & 1999 & 2000 & 2001 & 2002 & \\
\hline Total (ex. China) & 3.4 & 3.8 & 2.4 & -4.4 & -1.3 & 0.8 & -1.2 & -0.3 & \\
\hline \multirow[t]{2}{*}{ ASEAN-5 } & 6.6 & 9.1 & 4.4 & -6.6 & -5.7 & -3.1 & -3.6 & -1.3 & \\
\hline & 2003 & 2004 & 2005 & 2006 & 2007 & 2008 & 2009 & 2010 & 2011 \\
\hline Total (ex. China) & -0.4 & 1.5 & 0.9 & -0.2 & 0.4 & 1.2 & -1.1 & 3.5 & 2.1 \\
\hline ASEAN-5 & -1.2 & 1.0 & 2.3 & 0.8 & 1.2 & 1.3 & -3.5 & 2.2 & 4.0 \\
\hline
\end{tabular}

Source: Pradhan et al. (2011).

Even for advanced countries, interest differentials don't seem to be important: The flows between developed countries behave differently from the flows to emerging countries, but are no closer to the interest-based analytical framework. The gross flows in both directions have been huge, many times larger than the net flows. ${ }^{6}$ How is this consistent with the idea that interest differentials are the main, or even an important, driver of the flows? If that were true, countries would tend to have flows which were largely one-sided (either mainly inflows or mainly outflows), with the net flows not much smaller than the gross flows.

5 Defined, following IMF usage, as all of Asia excluding Japan, Australia, New Zealand, and low-income countries. 'ASEAN 5' comprises Indonesia, Thailand, Philippines, Malaysia and Vietnam, omitting the special case of financial-centre Singapore.

6 See IMF (2011): Figure 4.2. 
UIP doesn't hold: Uncovered interest parity is central to much of the financial market's analysis (for example, for the setting of forward exchange rates) and is an important element in making the case that financial markets are efficient. It is now abundantly clear that UIP offers feeble guidance for the exchange rate/interest rate nexus (see Engel 1996). UIP often gets the direction wrong (countries with higher interest rates appreciate rather than depreciate), let alone the magnitude (Cavalo 2006). This inability to predict the direction is familiar in East Asia in the period 2000-10 (Grenville 2011), where interest rates have often been higher than global norms while at the same time exchange rates have appreciated. $^{7}$

Capital flows 'uphill': For almost all of the last decade, emerging countries have been building up their foreign-exchange reserves (that is, investing in foreign assets) faster than foreign investment has been flowing into these countries. ${ }^{8}$ Capital is flowing uphill from the emerging countries to the mature industrial countries.

Exchange rates are volatile: Despite foreign-exchange markets being information-rich, long-established, deep and free of restriction, exchange rates are inexplicably volatile, not only in their daily movements, but also in their persistent swings. When exchange rates are driven by changes in capital flows, exchange-rate changes don't play much of a role in achieving equilibrium because rate expectations are often extrapolative (the higher price doesn't reduce demand; it increases it). Exchange rates (especially in emerging countries) are not well anchored (which would be the basis of reversion-to-mean stabilisation) because there is not widely accepted analytical knowledge of the underlying fundamentals to anchor the price. This is a chicken-and-egg problem: because exchange rates demonstrate inexplicable volatility, there is no accepted model which would anchor the rate in the face of temporary shocks. Markets spend more time guessing what other participants think than about the fundamentals.

Portfolio returns haven't equalised: Over a sustained decades-long period, higher returns have been available from investment in emerging countries. The return on investing in 2000 in one-year bonds in India, Korea, Singapore or Malaysia was greater than the US return by more than 30 per cent, and in Indonesia the return was 150 per cent higher. For equities, the higher relative return for the same countries ranged between $50-300$ per cent. ${ }^{9}$

7 For Indonesia, Malaysia, South Korea, the Philippines and Thailand, the average interest differential vis-àvis the US dollar in 2000-10 was positive, while the exchange rate appreciated over the decade. See Grenville (2012): Figure 2.

8 See Grenville (2012): Figure 5.

9 See Grenville (2012): Figure 6. 


\section{How well do the characteristics of the real world fit the analytical model?}

It's hard to argue that the portfolio balance perspective fits the real world at all closely. This framework explains flows in terms of interest differentials plus a conglomeration of other factors which are usually just called 'risk'. This catch-all term has three characteristics. It is often very large compared with the interest-differential explanation. Second, it is largely unexplained. Third, it is 'time variant'; that is, it varies very considerably in response to nebulous factors such as expectations. Analytically, this 'risk' term is a deus ex machina that is invoked to 'explain' the huge degree of unexplained variation of flows. In financial-market discussion, 'risk' is often treated as if it could be captured by some certainty-equivalent based on a well-formed view on probabilities (that is, as if the issue was Knightian risk), without any consideration of uncertainty (with unknown probability distribution), which is usually the more relevant concept.

We shouldn't be surprised that in the real world financial assets are very far from the close substitutes (that is, differing only by interest return and exchange rate expectations) usually envisaged in the models ${ }^{10}$ and UIP. The legal framework that supports financial assets differs fundamentally between countries. Underlying assets (fundamentally the collateral behind financial assets) vary hugely in their intrinsic characteristics, most importantly in their property rights.

Moreover, not only are the intrinsic characteristics different, but what matters for financial markets is the subjective assessments of financial assets. Some are easier to assess and to price and will remain fairly stable in price (for example, US-dollar bonds). But most foreign assets are poorly known by many of the big players in the markets (fund managers), and the cost of gathering reliable information is high. Most investors have a strong 'home-currency bias', and for good reason. They prefer to hold assets in their own country because they know the legal and institutional system, the tax rules and what legal recourse they have if anything goes wrong with their investment. As well, they generally know much more about the specific characteristics of home assets than foreign ones. Liquidity varies hugely between markets and varies over time with the whim of moods of optimism and pessimism. Transaction logistics can often be difficult. The institutional facilities to buy assets (say, equities) in the emerging countries of East Asia are much less easy for investors. Big fund managers develop the specialised expertise necessary for diverse investment, but even for large investors such investments will be a small part of the portfolio. Being a

10 For example, the Mundell/Fleming model. 
small part of the portfolio means that it is not worthwhile to expend too many resources gathering information: better to just cut and run when uncertainty increases.

Equilibria in flows and stocks, if they occur, are fleeting: we don't observe the flows stopping or even stabilising, as an indication that some portfolio balance has been achieved. What about the dynamic behaviour of the flows? The Dornbusch (1976) overshooting model provides a possible explanation, with its simple reconciliation for two assets offering different risk-adjusted interest returns. First there is a once-off appreciation of the higher-interest-rate country, then a depreciation which lasts the length of time the interest rates take to reach equilibrium. While there is no recorded example of this sequence in the real world, at least it seems intuitively plausible in the context of a cyclical movement in interest rates which opens up a temporary differential with foreign rates. But for the countries of East Asia, the interest differential is not cyclical. It is structural, reflecting the higher productivity and profitability available in these countries as they move towards the production frontier. They have higher Wicksellian (natural) real interest rates than the mature industrial countries, already at the production frontier. This differential is likely to last for some decades.

\section{The challenges for empirical analysis}

Most analytical work on capital flows focuses on net flows. This would be appropriate if the main action was in the national accounts (that is, if the savings/investment balance was the determinant of capital flows): the net capital flow would be the residual funding. If, however, the flows themselves are an important determinant of the overall outcome, this would require analysis in terms of gross rather than net flows (the decision-makers are usually focused on gross flows. The net figures confound multiple decision-makers). ${ }^{11}$

These are financial flows, recorded in the flow-of-funds accounts, and not directly reflected in the national accounts (see Borio and Disyatat 2011). If, for example, the foreigners buy an existing asset, then the chain of transactions which this sets off would have to be analysed to know what the effect is on the national accounts: it's not like just adding the dollar flow to the investment accounts.

11 Just to complicate the story, however, some inflows have closely related outflows (for example, with derivatives and forward cover, and when the country is acting as a financial intermediary for another country, as in Hong Kong vis-à-vis China). 
The decisions are portfolio choices, so we should be looking at stock positions rather than flows. And even here the outcome usually reflects the two sides of a transaction (for example, both borrower and lender), so questions of 'push' and 'pull' factors may both be relevant. The interconnection between the new portfolio equilibrium and economic activity (via wealth effects and relative interest-rate changes) is so complex that it will be hard to get a firm handle on it.

As well, the data (especially for the gross flows) are seriously incomplete. We do not have a proper handle on the volume of carry-trade (McCauley 2010) and important parts of the interaction (for example, derivatives offered by the branches of foreign banks and transactions taking place in the non-deliverable forward markets) may not be caught in the balance-of-payments data, even though their impact is similar to the flows which are recorded in the balance of payments.

In short, we are at a very early stage in understanding capital flows.

\section{The benefits from foreign investment have been mis-stated}

The case for free capital flows is usually given along the following lines (see IMF 2010: Box 1):

- Funding for investment can be obtained in larger volume and more cheaply.

- FDI brings technology and managerial skills.

- Consumption smoothing occurs in the face of adverse shocks.

- Risk is spread and portfolio diversification can occur.

- Flows provide discipline for macro policy.

In practice these advantages look much less compelling.

The obvious attraction of capital flows is the opportunity to fund extra investment. But emerging East Asia generally saves more than it invests. Current-account surpluses are the norm. On the surface, there is no obvious need to supplement domestic funding by drawing on foreign capital. There is little doubt that FDI has been very useful, but it is the technology and skills transfer that is useful, rather than the funding.

A closely related argument is that foreign funding is cheaper. But the cost of funding is the principal channel through which monetary policy operates to influence the level of domestic economic activity. To the extent that foreign funding is cheaper, this undermines the intent of monetary policy. 
What about the advantage of consumption smoothing ${ }^{12}$ There is no evidence of this in the emerging countries (Kose et al. 2007). In fact, the opposite occurs: capital flows are pro-cyclical, adding to consumption in the upswing and restraining it in the downswing. In the upswing, foreign funding gives borrowers more opportunity to overextend themselves. We shouldn't find this too surprising. Shifts in confidence are one of the central causes of cycles (and crises). Foreigners share the optimism of the upswing. When economic activity falls because of domestic lack of confidence, foreign funding is not going to step in to fill the shortfall.

In practice, the more likely cyclical sequence is that foreign capital enables the cyclical upswing to run longer. With a floating exchange rate, stronger activity appreciates the exchange rate, encouraging imports, thus holding inflation in check. 'Spilling' stronger demand into imports may soften the cycle (avoiding 'sudden stops'). If this extended sequence is being funded by foreign capital inflow (rather than being suddenly cut off through lack of foreign exchange that sometimes occurred in fixed-exchange-rate regimes), in this sense the inflows might be seen as smoothing the cycle. But this just postpones the problem and is not the sort of consumption smoothing envisaged in the textbooks.

In any case this sort of cyclical stabilisation might more usefully be done using the country's own foreign-exchange reserves: running down reserves during the strong phase of the cycle tightens liquidity rather than adding to it. Spilling excess demand is in any case a poor substitute for higher interest rates, which may be undermined by capital inflows.

What of the argument that international flows allow spread of risk and provide portfolio diversification benefits? Are domestic portfolios and balance sheets safer if they contain foreign liabilities, probably denominated in foreign exchange? Are domestic banks stronger if they obtain a significant part of their funding from overseas? ${ }^{13}$ Are foreigners who have invested part of their portfolios in foreign assets, probably in foreign currency, more likely to be stable holders? ${ }^{14}$ Put in these terms, the diversification benefits seem more likely to be perverse than helpful. Risk is spread to the least-knowledgeable, most-flighty holders of debt. The extra risk element in the form of the exchange rate component in the foreigners' return on investment exacerbates this volatility. ${ }^{15}$ McCauley (2010) argues that East Asia diversified by accepting foreign investment in equities and investing in safe assets as part of their foreign-exchange reserves,

12 A characteristic of the intertemporal models such as Obstfeld and Rogoff (1994).

13 Recall the 2008 Korean experience, when branches of foreign banks suddenly reversed their earlier capital inflows.

14 Japan, with its high ratio of government debt to GDP, is seen as stable because most of this is held domestically.

15 There are, however, cases where the opportunity of foreign diversification is clearly in the interests of the capital-receiving emerging country. It has been a long-standing part of Singapore's investment strategy 
preparing for upcoming problems. If emerging countries need to do this, are the short-term inflows such a good idea in the first place? The pro-cyclical action of foreign investors means that they don't 'accept their share of the poor harvest, in textbook fashion, but instead head for the exit' (McCauley 2010: 134).

There are clearly situations in which foreign capital flows can exert discipline over macroeconomic policies, with governments having a strong incentive to maintain good policies in order to avoid departure of flighty capital. This argument would be more powerful if markets had developed a reliable reputation for discerning and timely monitoring. Foreign investors, however, tend to follow imitative lemming-like correlated behaviour, and rating agencies have a well-established reputation for observing economies through the rearvision mirror, rather than in a forward-looking way. If excessive foreign flows encourage recipient countries to keep interest rates too low, this doesn't promote discipline. To the extent that foreign inflows cause the exchange rate to be above its long-term equilibrium, it is hard to see this as exercising helpful macroeconomic discipline. ${ }^{16}$

So much for the usual arguments in favour of foreign capital. One rarely mentioned advantage is that foreign financial centres may provide a range of useful financial services not available in the home country. Singapore may provide this for Indonesia's corporate and banking sector; Hong Kong for China; and New York for a range of countries (including countries with mature financial markets such as Australia). ${ }^{17}$

To balance the evaluation of this rather modest list of advantages, we need to recall the financial fragility and prudential problems discussed above in relation to specific countries in East Asia. ${ }^{18}$ We also need to note that the policy responses to capital reversals are usually ineffective. In particular, higher interest rates are impotent in halting outflows when there are doubts about the health of the financial system and the exchange rate is under pressure.

to encourage both inflows of FDI and outflows of investment capital, to diversify what would otherwise be a narrow range of assets, excessively correlated with the performance of the domestic economy. It is worth noting that this diversification is initiated and managed by the recipient country.

16 The issue of discipline may also be relevant at the micro level. When there is a direct relationship between borrower and lender, the foreign lender may provide effective and appropriate discipline on the domestic borrower (just as a domestic direct lender would). But much of foreign inflow occurs in an indirect way (with the foreigner holding a market instrument such as a bond) without direct connection between foreign lender and domestic borrower.

17 Does this ability to get foreign funding easily inhibit the growth in the domestic financial market? It is often argued that this is the reason for the thin corporate bond market in Australia, and may explain the small size of the Indonesian financial sector. This view can be seen in the argument that china is not yet able to provide the full range of intermediation, so sends its surplus funds to be invested in safe US assets (foreignexchange reserves), with the US sending part of this back in the form of risk-capital investments into China. 18 OECD (2011) shows that emerging countries that have experienced large capital inflows are more likely to experience a banking crisis. 


\section{Are the suggested remedies appropriate ${ }^{19}$}

The exchange rate should appreciate if the rate is undervalued: This seems selfevident but irrelevant to the problem: these emerging countries find themselves with continuing upward pressure on their exchange rates and this is unwelcome because of loss of international competitiveness. They see their problem as overvaluation rather than undervaluation.

Exchange rate intervention: Earlier IMF views that intervention would have no effect on the exchange rate may have been softened, suggesting that intervention is acceptable provided it doesn't distort monetary policy. ${ }^{20}$ Even this may exaggerate how far the IMF has moved: this intervention is sometimes put forward as a method of augmenting an inadequate level of foreign-exchange reserves, leaving unresolved the question whether intervention policy might also legitimately be used to constrain an appreciation.

Fiscal tightening to make room for expenditure associated with the inflow: There seems universal support for this strategy, ${ }^{21}$ but it is rarely relevant to the core problem of capital inflow. If the domestic cycle is running too strongly, selfevidently there is always opportunity for fiscal restraint, regardless of capital flows. If the domestic economy is not running too strongly (but the capital flows are causing uncomfortable upward pressure on the exchange rate), tighter fiscal policy seems more likely to exacerbate the appreciation rather than help. Tighter fiscal policy (that increases national saving relative to investment) will tend to push the current account more towards surplus. Accommodating the capital flows within a current account that is in greater surplus will require appreciation of the exchange rate. ${ }^{22}$ Thus the remedy gives a perverse outcome. In any case, what is the rationale for reducing budget expenditure or raising revenue in order to make room for the foreign capital? There is an unwarranted presumption here that the foreign capital gives rise to more useful activity than the budget. Why should foreign capital be encouraged at the expense of budget priorities?

Macro-prudential measures: These have been put forward as the new panacea for excessive capital flows. ${ }^{23}$ To the extent that capital flows present a threat

19 For a typical enumeration of the IMF-endorsed responses, see Ostry et al. (2011).

20 The IMF is still confused in making the distinction between sterilised and unsterilised intervention. In practice, intervention is always sterilised.

21 For example, see Yellen (2011).

22 The standard textbook IS/LM diagram, showing the relationship between the savings/investment balance and monetary liquidity, is misleading here. It implies that the tighter fiscal policy will reduce interest rates and thus discourage capital inflow. However, modern monetary policy sets interest rates directly (for many, the Taylor Rule replaces the LM). Thus there is no reason to expect tighter fiscal policy to affect interest rates and hence discourage inflows.

23 There is a comprehensive discussion of these possibilities in Ostry et al. (2011). 
to financial stability, these are certainly an appropriate response. But issues related to the stability of the financial system should not depend on whether or not capital flows are excessive at the macro level. If substantial fundraising on foreign money markets presents a vulnerability to the banking system, then that is itself the rationale for restriction. Restraining the banks from providing foreign-currency denominated loans may make sense to protect the domestic banks from currency mismatch, regardless of what is happening to capital flows.

Overall vulnerability will often be reduced by effective macro-prudential policies. It seems quite possible, however, that macro-prudential measures might, themselves, push the problems elsewhere rather than resolving them. For example, restricting banks from providing foreign-currency loans or receiving foreign-currency funding might encourage non-bank borrowers to seek foreign funds directly from overseas intermediaries, which might be potentially more dangerous than if the inflow occurred via the domestic banking system.

\section{What this means for policy}

While the IMF's recognition of these issues is belated and incomplete, it holds out the best opportunity to develop a more relevant policy agenda (see IMF $2012 \mathrm{a}$ and b). In embryonic form, it has already put in place the elements from which an effective policy could be developed:

- There is a recognition that the usual array of conventional policy instruments could be used to discourage excessive inflows. Macro-prudential measures which limit domestic banks' overseas borrowing and limitations on the issuance of those types of securities which are most favoured by foreign investor should be part of the policy toolbox.

- When all else fails, the IMF envisages that capital-flows management might be undertaken. This includes the various taxation measures (for example, Chile's encaja and Brazil's taxes). The Fund has been, to a large extent, responsible for the stigma surrounding management of capital flows. Thus it should assume primary responsibility for removing the stigma by endorsing these management measures more fully.

- Since 2009 the Fund has been carrying out the Multilateral Assessment Program (MAP), focused on external imbalances. More recently still, it has produced a Pilot External Sector Report (IMF 2012c) which calculates external divergences: 'the gap between actual current account balances and those estimated by staff to be consistent with fundamentals and desirable policies. They reflect distortions and should be eliminated.' It also calculated 'estimated differences between real effective exchange rates and those consistent with fundamentals and desirable policies'. While this discussion 
often emphasises the current account, this Report explicitly covers the counterpart capital flows.

- Some broad notion of the fundamental equilibrium exchange rate (FEER) is needed for effective intervention. The IMF calculates three different versions of FEER (IMF 2006). While there are obviously wide margins of uncertainty around these calculations (as there are with all policy variables), these will be the basis for policy options on intervention. This is at least the start of a rational policy framework. Some official endorsement of a broad band for the exchange rate (such as Singapore gives) may anchor market expectations effectively. Williamson's (2008) Band/Basket/Crawl (BBC) offers more specifics. Capital flows which are not disruptive of the exchange rate require no policy response: variations of the exchange rate within the band would be accepted. Temporary departures outside the band would be handled with foreign-exchange market intervention. Persistent departures from the band require closer policy analysis: is this a new equilibrium, to which the economy should adapt, accepting the stronger exchange rate?

\section{Conclusion}

The three-decade-long period when the main thrust of policy advice was to open up capital accounts and allow free flows of international capital has left a policy vacuum for the real world, in which capital flows can be excessive, volatile and cause disruption to exchange rates and interest rates.

This blinkered policy perspective has left many unresolved issues. What, for instance, should emerging countries with substantially higher growth and profit prospects (and thus permanently higher Wicksellian interest rates) do over time if this causes excessive capital inflow? There may be a case for ad hoc 'sand in the wheels' to keep the flow of foreign capital from opening up a substantial current-account deficit which leaves the economy vulnerable to volatile changes in sentiment. The IMF has come a long way in recent years in recognising the challenges which capital flows impose on emerging countries. But translating this into an effective policy framework is still a work in progress.

\section{References}

Bhagwati, J. 1998, 'The capital myth: the difference between trade in widgets and dollars', Foreign Affairs 77: 7-12.

Borio, C. and Disyatat, P. 2011, 'Global imbalances and the financial crisis: Link or no link?’ BIS Working Papers 346. 
Cavalo, M. 2006, 'Interest Rates, Carry Trades, and Exchange Rate Movements', FRBSF Economic Newsletter 31.

Dornbusch, R. 1976, 'Expectations and exchange rate dynamics', Journal of Political Economy 84(6): 1161-76.

Engel, C. 1996, 'The forward discount anomaly and the risk premium: a survey of recent evidence', Journal of Empirical Finance 32: 305-19.

Grenville, S. 2011, 'The Impossible Trinity and Capital Flows in East Asia', ADBI Working Paper 319.

2012, 'Rethinking Capital Flows for Emerging East Asia', ADBI Working Paper 362.

IMF IEO 2005, 'Report on the Evaluation of the IMF's Approach to Capital Account Liberalization'.

IMF 2006, 'Methodology for CGER Exchange Rate Assessments'.

2010, 'The Fund's role regarding cross-border capital flows' .

_ 2011, 'World Economic Outlook April'.

_2012a, 'Liberalizing Capital Flows and Managing Outflows Background paper'.

2012b, 'Liberalizing Capital Flows and Managing Outflows — Policy paper'.

2012c, Pilot External Sector Report.

Kose, M. A., Prasad, E., Rogoff, K. and Wei, S-J. 2006, 'Financial Globalization: A Reappraisal', IMF Working Papers 06/189.

McCauley, R. N. 2010, 'Managing Recent Hot Money Inflows in Asia' in Kawai, M. and Lamberte, M., Managing Capital Flows: The Search for a Framework.

OECD 2011, 'Getting the most out of capital flows', Economic Outlook, Chapter 6.

Obstfeld, M. and Rogoff, K. 1994, 'The intertemporal approach to the current account', NBER Working Paper No. 4893.

Ostry, J. D., Ghosh, A. R., Habermeier, K., Chamon, M., Qureshi, M. S. and Reinhardt, D. B. S. 2010, 'Capital Inflows: The Role of Controls', IMF Staff Position Note SPN/10/04. 
Ostry, J. D., Ghosh, A. R., Habermeier K., Laeven, L., Chamon, M., Qureshi, M. and Kokenye, A. 2011, 'Managing Capital Inflows: What Tools to Use?', IMF Staff Discussion Note 11/06.

Pradhan, M., Balakrishnan, R., Baqir, R., Heenan, G., Sylwia Nowak, C. O. and Panth, S. 2011, 'Policy Responses to Capital Flows in Emerging Markets', IMF Staff Discussion Note 11/10.

Williamson, J. 2008, 'Exchange Rate Economics', Peterson Institute Working Paper 08/03, February.

Yellen, J. L. 2011, 'Reaping the Full Benefits of Financial Openness', Bank of Finland 200th Anniversary Conference Helsinki, Finland. 